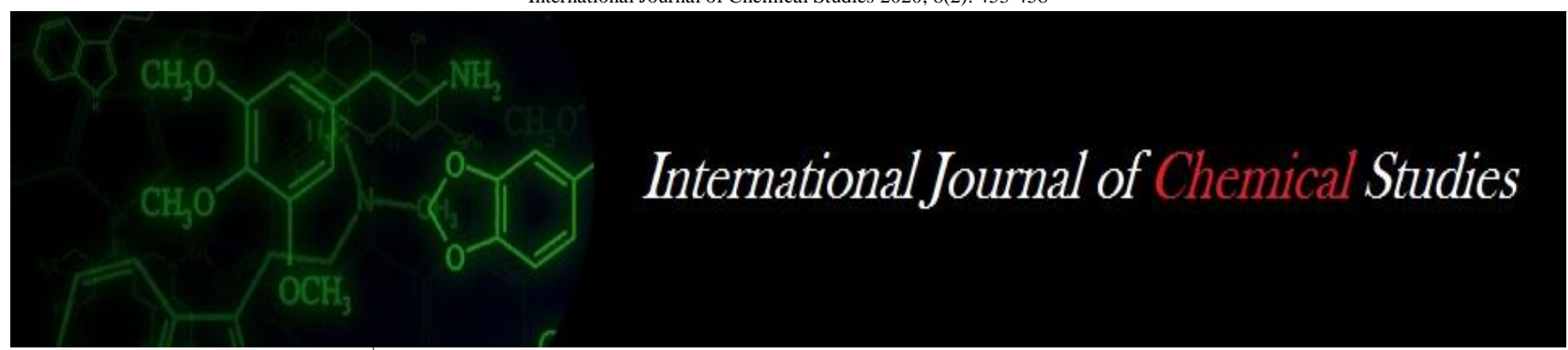

P-ISSN: 2349-8528

E-ISSN: 2321-4902

www.chemijournal.com

IJCS 2020; 8(2): 453-458

(C) 2020 IJCS

Received: 14-01-2020

Accepted: 17-02-2020

\section{Jayshive Patidar}

Department of Agriculture,

Mandsaur University, Mandsaur,

Madhya Pradesh, India

\section{YM Sharma}

Department of Soil Science and

Agricultural Chemistry,

Jawaharlal Nehru Krishi Vishwa

Vidyalaya, Jabalpur,

Madhya Pradesh. India

\section{GS Tagore}

Department of Soil Science and Agricultural Chemistry,

Jawaharlal Nehru Krishi Vishwa

Vidyalaya, Jabalpur,

Madhya Pradesh, India
Corresponding Author:

GS Tagore

Department of Soil Science and

Agricultural Chemistry,

Jawaharlal Nehru Krishi Vishwa

Vidyalaya, Jabalpur,

Madhya Pradesh, India

\section{Assessment of phosphorus fixing capacity in contrasting soil orders in central India}

\author{
Jayshive Patidar, YM Sharma and GS Tagore
}

DOI: https://doi.org/10.22271/chemi.2020.v8.i2g.8810

\begin{abstract}
Phosphate adsorption by soils is important because adsorbed $\mathrm{P}$ equilibrates with soil solution $\mathrm{P}$, which in turn is immediate source of $\mathrm{P}$. While $\mathrm{P}$ fixation continues to receive much attention it is more important to know the effect of soil characteristics on P fixation. Phosphorus sorption characteristics of JNKVV, Farm, Jabalpur representative agricultural soils belonging to three soil orders namely Vertisol, Inceptisol and Alfisol were investigated for adsorption behaviour of $\mathrm{P}$ and sorption data were fitted to Langmuir equation. The Langmuir constant i.e. adsorption maxima was highest for Vertisol $\left(504.26 \mu \mathrm{g} \mathrm{g}^{-1}\right)$, followed by Alfisol (480.89 $\left.\mu \mathrm{g} \mathrm{g}^{-1}\right)$ and Inceptisol $\left(452.98 \mu \mathrm{g} \mathrm{g}^{-1}\right)$ respectively. The phosphate adsorption isotherm gave good fit adopting Langmuir $\left(\mathrm{r}^{2}=0.98\right.$ to 0.99$)$ for the three soils. The value of equilibrium solution $\mathrm{P}$ concentrations were found significantly variation under different soil orders but the adsorb $\mathrm{P}$ value was also found significant varied. The equilibrium solution $\mathrm{P}$ concentrations minimum in Alfisols 0.03 to $8.95 \mathrm{mg} \mu \mathrm{g} \mathrm{mL} \mathrm{L}^{-1}$ and maximum in Inceptisols 0.09 to $10.95 \mu \mathrm{g} \mathrm{mL}^{-1}$, but the adsorb $\mathrm{P}$ value was minimum in Inceptisols 19.01 to $290.41 \mu \mathrm{g} \mathrm{mL}^{-1}$ and maximum were recorded in Alfisols 19.64 to $310.47 \mu \mathrm{g} \mathrm{mL}^{-1}$. In Vertisols the value of equilibrium solution $\mathrm{P}$ concentrations were found in the range of 0.13 to $10.08 \mu \mathrm{g} \mathrm{mL}^{-1}$ and adsorb $\mathrm{P}$ values were 18.65 to $299.13 \mu \mathrm{g} \mathrm{mL}^{-1}$. The range of $\mathrm{P}$ buffering capacity was 60.07 to $70.89 \mathrm{~L} \mathrm{~kg}^{-1}$. The highest value of MPBC was found in Alfisols with the mean value $68.89 \mathrm{~L} \mathrm{~kg}^{-1}$ and the lowest of MPBC value was found in the Inceptisols with the mean value was $63.72 \mathrm{~L} \mathrm{~kg}^{-1}$. Correlation of Adsorption parameters of Langmuir and were worked out taking all soil types together with $\mathrm{pH}, \mathrm{EC}$, organic carbon, clay, $\mathrm{CEC}$ and $\mathrm{CaCO}_{3}$. For the Lamgmuir equation, value of ' $\mathrm{r}$ ' indicated that $\mathrm{P}$ adsorption maxima (b) was significantly and positively correlated with $\mathrm{pH}\left(\mathrm{r}=0.993^{* *}\right)$, clay $\left(0.916^{* *}\right) \mathrm{EC}(\mathrm{r}=0.734 *)$.
\end{abstract}

Keywords: Phosphorus, sorption maxima, vertisol, inceptisol, alfisol, standard P requirement

\section{Highlights}

- Soils were found neutral to slightly alkaline in soil reaction, safe in electrical conductivity, low to medium in organic carbon content and non- calcareous nature.

- The adsorption in three major soil orders of illustrated that the Langmuir models can be used to describe satisfactorily $\mathrm{P}$ sorption on soil colloids. Among the three soil orders highest $\mathrm{P}$ sorption was observed in Vertisol followed by, Alfisol and Inceptisol.

- Correlation of P sorption maxima with clay content illustrating that soil texture played a major role in $\mathrm{P}$ sorption of these soils.

- The SPR values indicated high P requirement in Inceptisols as compared to Alfisols and Vertisols to maintain $0.2 \mathrm{mg} \mathrm{P} \mathrm{L}^{-1}$ in soil solution for optimum crop growth. The high $\mathrm{P}$ adsorption by Vertisols showed higher phosphate buffering capacity and would maintain low $\mathrm{P}$ in soil solution $\mathrm{P}$ as compared to Alfisols and Inceptisols.

\section{Introduction}

Phosphorus sorption governs the supply of labile inorganic P (fertilizer P) and the isotherm helps in predicting the efficiency of crops to utilize that labile P. It is a well-known fact that phosphate adsorption depends upon many soil properties like clay content, $\mathrm{CaCO}_{3}$, organic matter, Al and Fe content, CEC as well as P sources applied to soil (Saha et al., 1999; Majumdar et al., 2005) ${ }^{[18,10]}$.

In order to understand the complex behaviour of $\mathrm{P}$ in soil, several workers have emphasized the importance of $\mathrm{P}$ fertilizer management based upon chemical extraction methods (soil-test methods) and phosphate adsorption isotherms (Hue et al., 2000) ${ }^{[6]}$. But, P sorption method has 
an edge over chemical extraction methods as it also defines the efficiency of the crops to utilize the $\mathrm{P}$ available from soil. Sorption curves also integrate quantity and intensity parameters to characterize the capacity of soil to supply $\mathrm{P}$ to soil solution and predicting fertilizer requirement. Adsorption equations of Langmuir have been used by many workers worldwide to measure relative phosphate sorption capacity of different soils and the affinity of adsorbate to adsorbent, to understand the sorption phenomenon.

The availability of phosphorus is controlled by the fixation mechanism. Prediction of response to $\mathrm{P}$ application is generally based on available $\mathrm{P}$ status as well as on the rate and magnitude at which the added $\mathrm{P}$ is converted into insoluble forms in soil (Tekchand and Tomar, 1993) ${ }^{[21]}$. Phosphate adsorption by soils is important because adsorbed $\mathrm{P}$ equilibrates with soil solution $\mathrm{P}$, which in turn is immediate source of $\mathrm{P}$. While $\mathrm{P}$ fixation continues to receive much attention it is more important to know the effect of soil characteristics on $\mathrm{P}$ fixation.

\section{Material and Method}

\subsection{Description of study area and sites}

Jawaharlal Nehru Krishi Vishwa Vidyalaya, Jabalpur, is situated $23^{\circ} 12^{\prime} 57^{\prime}$ " latitude and 79 $56^{\prime} 49^{\prime \prime}$ longitude and altitude of $383.3 \mathrm{~m}$ above mean sea level. Breeder Seed Production of Field Crops (BSP-FC) in which dominant soils were Vertisol, classified as Typic Haplusterts, Family-Very fine montmorillonite hyperthermic (Tripathi 1998) ${ }^{[24]}$ and Inceptisol, Vertic Ustochrept, fine mixed hyperthermic
(Kulkarni, 1986) ${ }^{[8]}$. The soils of BSP-FC Farm are clayey in texture.

Krishi Nagar Research Farm in which soil order was Alfisol and classified as Typic and Vertic Haplustalf, Fine loamy and mixed, hyperthermic, locally knew as sehra soils. The texture was found to be sandy clay loam and sandy loam (Dhakad, 2017) ${ }^{[2]}$

Breeder Seed Production of Groundnut (BSP-Groundnut) in which soil type was Inceptisol and classified as Typic Ustochrept, Fine loamy and mixed, hyperthermic (Tripathi, 1998) ${ }^{[24]}$.

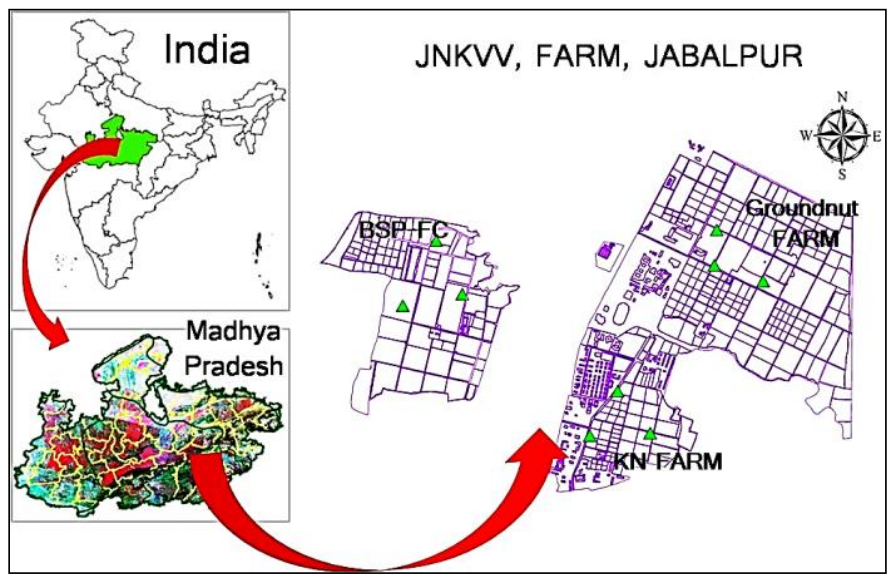

Fig 1: Location of Soil sampling

Table 2.1: Details of soil used

\begin{tabular}{|c|c|c|c|c|c|c|}
\hline Farm & Soil orders & Site & Latitude & Longitude & Cropping system & Sample No. \\
\hline \multirow{3}{*}{ BSP-Field Crops } & \multirow{3}{*}{ Vertisols } & (V1) & N-23013'02.4"' & S-79056'40.7”' & Soybean-Wheat & \multirow{3}{*}{3} \\
\hline & & (V2) & N-23012'50.1" & S-79056'47.0" & Soybean-Wheat & \\
\hline & & (V3) & N-23013'44.6" & S-79056'36.7" & Soybean-Wheat & \\
\hline \multirow{3}{*}{$\begin{array}{l}\text { Krishi Nagar } \\
\text { Research Farm }\end{array}$} & \multirow{3}{*}{ Alfisols } & (A1) & N-23012'17.6”' & S-79057'17.6" & Rice-Wheat & \multirow{3}{*}{3} \\
\hline & & (A2) & N-23012'18.2” & S-79057'32.1" & Rice-Wheat & \\
\hline & & (A3) & N-23012'27.8” & S-79057'24.3"' & Rice-Wheat & \\
\hline \multirow{3}{*}{ BSP-Groundnut } & \multirow{3}{*}{ Inceptisols } & (I1) & N-23012'53.1"' & S-79057'59.2”' & Rice-Wheat & \multirow{3}{*}{3} \\
\hline & & (I2) & N-23012'56.7' & S-79057'47.5" & Rice-Wheat & \\
\hline & & (I3) & N-23013'04.8' & S-79057'48.1" & Rice-Wheat & \\
\hline
\end{tabular}

\subsection{Physico-chemical properties of soils}

The soil $\mathrm{pH}$ was measured in a soil: water ratio of 1: 2.5 using the $\mathrm{pH}$ meter and supernatant of same was used for electrical conductivity determination with the help of conductivitymeter (Jackson, 1973) ${ }^{[7]}$. Organic carbon (OC) in soil was determined using method as described by (Walkley and Black 1934). The calcium carbonate in soil was carried out using rapid back titration method as described by (Jackson, 1973) [7]. The CEC of soil was analyzed by leaching it with $1 \mathrm{~N}$ neutral $\mathrm{NH}_{4} \mathrm{OAc}$ solution as described by (Jackson, 1973) ${ }^{[7]}$. The particle size analysis (clay percent) of soil was determined by Bouyoucos hydrometer method (Bouyoucous, 1962) ${ }^{[1]}$. Available nitrogen (N) was determined as per method given by Subbiah and Asija (1956) ${ }^{[20]}$. Available phosphorus $(\mathrm{P})$ was determined by $0.5 \mathrm{M}$ sodium bicarbonate by Olsen et al., (1954) [12] and then read on Spectrophotometer. Available potassium (K) was extracted with $1 \mathrm{~N} \mathrm{NH}_{4} \mathrm{OAc}$ and then measured by Flame Photometer (Jackson, 1973) ${ }^{[7]}$.

\subsection{Determination of phosphorus fixing capacity of the soils}

For determination of phosphate adsorption characteristics of soil, the method suggested by Fox and Kamprath (1970) ${ }^{[5]}$ was followed triplicate soil sample $(3 \mathrm{~g})$ were equilibrated with $30 \mathrm{ml}$ of $0.01 \mathrm{M} \mathrm{CaCI}$ solution containing graded concentrations of $\mathrm{P}\left(2,4,8,16,24,32\right.$ and40 $\mathrm{mg} \mathrm{P} \mathrm{L}^{-1}$ Potassium dihydrogen phosphate) in $50 \mathrm{ml}$ plastic centrifuge tubes for six days at $25 \pm 1^{\circ} \mathrm{C}$. Two drops of toluene were added to suspensions to inhibit microbial activity. During the equilibration period, the soil suspensions were shaken for 30 min twice daily. After six days of equilibration, the suspensions were centrifuged and filter the Whatman filter paper and $\mathrm{P}$ concentrations in the supernatants were determined colorimetrically (Olsen et al., (1954) ${ }^{[2]}$. The amount of $\mathrm{P}$ sorbed was calculated by the difference between $\mathrm{P}$ initially added and $\mathrm{P}$ remaining in solution. The phosphate adsorption data were fitted to the Classical Langmuir Isotherm equation for evaluating the goodness of fit. The different equations used are described below.

$$
\stackrel{\mathrm{C}}{=} \frac{1+\underline{\mathrm{C}}}{\mathrm{Q} \mathrm{kb}}
$$

Where, $\mathrm{C}$ is the solution $\mathrm{P}$ concentration $\left(\mathrm{mg} \mathrm{P} \mathrm{L}^{-1}\right), \mathrm{q}$ is the amount of sorbed $\mathrm{P}\left(\mathrm{mg} \mathrm{P} \mathrm{kg}{ }^{-1}\right)$, $\mathrm{b}$ is the $\mathrm{P}$ sorption maximum (mg $\mathrm{P} \mathrm{kg}$ sorption) and $\mathrm{k}$ is the constant related to bonding 
energy of sorption $\left(\mathrm{mg} \mathrm{kg}^{-1}\right)$. The sorption maximum (b) and bonding energy $(\mathrm{k})$ were computed from slope and intercept of the Langmuir $\mathrm{P}$ sorption isotherms, respectively. The maximum $\mathrm{P}$ buffering capacity (MPBC) was calculated by multiplying sorption coefficients, $\mathrm{b}$ and $\mathrm{k}$ advocated by Kuo et al., (1988) ${ }^{[9]}$. Further, standard P requirement of soil (SPR) was determined as amount of $\mathrm{P}$ sorbed at a solution $\mathrm{P}$ concentration of $0.2 \mathrm{mg} \mathrm{P} \mathrm{L}^{-1}$ (Fox and Kamprath, 1970) ${ }^{[5]}$.

\subsection{Result and discussions}

\subsection{Status of physico-chemical properties of soil}

Data presented in table 3.1 showed that soil $\mathrm{pH}$ of different soil order of JNKVV farm Jabalpur, found to be 7.57, 7.59 and 7.68, 6.37, 6.95 and 7.18 and 6.72, 6.27 and 6.35 in V1, V2 and V3 (Vertisols), A1, A2 and A3 (Alfisols) and I1, I2 and I3 (Inceptisols) soil orders, respectively. Data indicates the $\mathrm{pH}$ of soils was found to be high in Vertisols (7.68) whereas low in Inceptisols (6.27). Raghuwanshi et al. (1992) ${ }^{[15]}$ analyzed Brown soils were slightly acidic (pH 5.6 to 6.6) while the black soil of Jabalpur was neutral to alkaline $(\mathrm{pH}$ 7.2). Similar ranges in $\mathrm{pH}$ values were also reported by Tripathi et al., (1994) ${ }^{[25]}$. In all the three soil orders the EC ranged from 0.07 to $0.35 \mathrm{dS} \mathrm{m} \mathrm{m}^{-1}$ at $25^{\circ} \mathrm{C}$. Which was safe in limite the three soil order $<1 \mathrm{dSm}^{-1}$ at $25^{\circ} \mathrm{C}$. Similar results for various black soils were also reported by Tomar (1968) [23] and Singh et al. (2014) ${ }^{[19]}$.

The organic carbon content in soil ranged from 4.60 to $6.60 \mathrm{~g}$ $\mathrm{kg}^{-1}$ in different orders of soil. The highest content of $\mathrm{OC}$ is recorded in Vertisol, which were $6.60,5.92$ and $5.87 \mathrm{~g} \mathrm{~kg}^{-1}$ in $\mathrm{V} 2, \mathrm{~V} 1$ and V3, respectively. In Alfisols, the OC content found to be 5.33, 5.25, and $4.80 \mathrm{~g} \mathrm{~kg}^{-1}$ in $\mathrm{A} 1, \mathrm{~A} 3$ and $\mathrm{A} 2$, respectively. However, organic carbon content in Inceptisols was observed to be low in I3, I2 and I1 which having value of $5.64,5.55$ and $4.60 \mathrm{~g} \mathrm{~kg}^{-1}$ respectively. Organic carbon was found to be low in Inceptisols and the high in Vertisols. The OC high might be due to incorporation of organic matter on the upper layer of the soil, through roots and other plant residues and manures. The crop species and cropping systems that may also play an important role in maintaining SOC stock because both quantity and quality of their residues that are returned to the soils vary greatly affecting their turnover or residence time in soil and thus its quality.

The $\mathrm{CaCO}_{3}$ content was found to be $40,60,45 \mathrm{~g} \mathrm{~kg}^{-1}$ and 60 , 70, $40 \mathrm{~g} \mathrm{~kg}^{-1}$ and $65,70,45 \mathrm{~g} \mathrm{~kg}^{-1}$ in $\mathrm{V} 1, \mathrm{~V} 2$ and $\mathrm{V} 3$ (Vertisols), A1, A2 and A3 (Alfisols) and I1, I2 and I3 (Inceptisols) soil orders, respectively. The data indicates that the lowest and the highest values were observed in Vertisols and Inceptisols, respectively. Concentration of $\mathrm{CaCO}_{3}$ is high might be due to least leaching process. It is concluded that the soils are non-calcareous in nature. Similar results were reported by Singh et al. (2014) ${ }^{[19]}$. The highest CEC content was found to be 58.24, 62.78, $55.23 \mathrm{cmol}(\mathrm{p}+) \mathrm{kg}^{-1}$ in V1, V2 and V3 (Vertisols) fallowed by 44.95, 48.21, $47.53 \mathrm{cmol}(\mathrm{p}+)$ $\mathrm{kg}^{-1}$ and $45.75,48.94,46.72 \mathrm{cmol}(\mathrm{p}+) \mathrm{kg}^{-1}$ in, A1, A2 and A3 (Alfisols) and I1, I2 and I3 (Inceptisols) soil orders. The minimum CEC was existed in Alfisols and Inceptisols. However it was maximum in Vertisols, Existence of higher CEC in soils of Vertisols might be due to presence of higher clay content. Pathak (1983) ${ }^{[13]}$ reported that CEC of clay soils derived from basaltic rocks increased with clay content. Similar results were also reported by Matike et al., (2011) ${ }^{[11]}$ and Singh (2014) ${ }^{[19]}$.

Table 3.1: Physico-chemical properties of different soils of JNKVV Farm, Jabalpur

\begin{tabular}{|c|c|c|c|c|c|c|c|c|c|}
\hline \multirow{2}{*}{ Site } & \multirow{2}{*}{ pH } & \multirow{2}{*}{$\mathrm{EC}\left(\mathrm{dSm}^{-1}\right)$} & \multirow{2}{*}{ OC $\left(\mathrm{gkg}^{-1}\right)$} & \multirow{2}{*}{$\operatorname{CaCO3}\left(\mathrm{gkg}^{-1}\right)$} & \multirow{2}{*}{$\operatorname{CEC}\left[\operatorname{cmol}(p+) \mathrm{kg}^{-1}\right]$} & \multirow{2}{*}{$\begin{array}{c}\text { Clay } \\
(\%)\end{array}$} & \multicolumn{3}{|c|}{ Available major nutrient $\left(\mathrm{kgha}^{-1}\right)$} \\
\hline & & & & & & & $\mathbf{N}$ & $\mathbf{P}$ & K \\
\hline (V1) & 7.57 & 0.35 & 5.92 & 40.00 & 58.24 & 50 & 267.79 & 16.24 & 328.68 \\
\hline (V2) & 7.59 & 0.26 & 6.60 & 60.00 & 62.78 & 55 & 302.70 & 11.09 & 308.32 \\
\hline (V3) & 7.68 & 0.22 & 5.87 & 45.00 & 55.23 & 52 & 250.88 & 15.15 & 345.60 \\
\hline (A1) & 6.37 & 0.16 & 5.33 & 60.00 & 44.95 & 25 & 279.97 & 30.53 & 298.08 \\
\hline (A2) & 6.95 & 0.12 & 4.80 & 70.00 & 48.21 & 20 & 245.06 & 30.79 & 276.96 \\
\hline (A3) & 7.18 & 0.15 & 5.25 & 40.00 & 47.53 & 22 & 276.97 & 24.91 & 322.80 \\
\hline (I1) & 6.72 & 0.08 & 4.60 & 65.00 & 45.75 & 25 & 239.14 & 21.34 & 336.08 \\
\hline (I2) & 6.27 & 0.09 & 5.55 & 70.00 & 48.94 & 30 & 251.06 & 17.60 & 323.36 \\
\hline (I3) & 6.35 & 0.07 & 5.64 & 45.00 & 46.72 & 32 & 272.23 & 22.00 & 289.76 \\
\hline
\end{tabular}

\subsection{Status available major nutrients in soils 3.2.1 Available N}

The data pertaining to available major nutrients, presented in table 3.1 indicated that the low available $\mathrm{N}$ content was recorded in Inceptisols soil order, which showing value of $272.23,251.06$ and $239.14 \mathrm{~kg} \mathrm{ha}^{-1}$ in I3, I2 and I1, respectively. In Alfisols, the available $\mathrm{N}$ was recorded to be 279.97, 276.83 and $245.06 \mathrm{~kg} \mathrm{ha}^{-1}$ in A1, A3 and A2, respectively. However, the available $\mathrm{N}$ content in soils was observed to be high in Vertisols, which having value of $302.70,267.79$ and $250.88 \mathrm{~kg} \mathrm{ha}^{-1}$ in V2, V1 and V3, respectively. The low nitrogen content in the soils is attributed due to high temperature, removal of organic matter leading to nitrogen deficiency. The medium nitrogen status in some area may be due to application of $\mathrm{N}$ fertilizer recommended for the crops. Soils with higher levels might be the contribution from the leguminous cover crops for the crops and very little tillage. Similar results were reported by Dubliya, 2011 and Singh et al., (2014) ${ }^{[19]}$; Ravikumar and Somashekar (2014) [7]

\subsubsection{Available $P$}

The available phosphorus content in soils of V1, V2 and V3; A1, A2 and A3; I1, I2 and I3 was recorded to be 16.24, 11.09 and $15.15 \mathrm{~kg} \mathrm{ha}^{-1} ; 30.5330 .79$ and $24.91 \mathrm{~kg} \mathrm{ha}^{-1} ; 22.00,17.60$ and $22.00 \mathrm{~kg} \mathrm{ha}^{-1}$ respectively. This high available $\mathrm{P}$ content is attributed to the regular application of phosphatic fertilizers and the immobile nature of phosphate ions in soils, which must have resulted in accumulation of $\mathrm{P}$ in soils. Results were supported by Ravikumar and Somashekar (2014) ${ }^{[7]}$ similar results were reported by Dubliya, 2011 and Singh et al., (2014) ${ }^{[19]}$.

\subsubsection{Available K}

The available $\mathrm{K}$ content in V1, V2 and V3 (Vertisols) were $328.68,308.32$ and $345.60 \mathrm{~kg} \mathrm{ha}^{-1}$, respectively. The $\mathrm{K}$ was recorded in I3, I1 and I2 (Inceptisols) with value of 389.76 , 346.08 and $323.36 \mathrm{~kg} \mathrm{ha}^{-1}$ respectively. The available $\mathrm{K}$ was found to be 276.96, 352.80 and $358.08 \mathrm{~kg} \mathrm{ha}^{-1}$ in A2, A3 and A1, (Alfisols) respectively. The available $\mathrm{K}$ content in Vertisols were $328.68,308.32$ and $345.60 \mathrm{~kg} \mathrm{ha}^{-1}$ in V1, V2 
and V3. The high value of $\mathrm{K}$ recorded in Inceptisols were $389.76,346.08$ and $323.36 \mathrm{~kg} \mathrm{ha}^{-1}$ in I3, I1 and I2, respectively. Among the Alfisols order the available $\mathrm{K}$ found 276.96, 352.80 and $358.08 \mathrm{~kg} \mathrm{ha}^{-1}$ in A2, A3 and A1, respectively. The high status of $\mathrm{K}$ in these soils may be due to predominance of $\mathrm{K}$ rich micaceous and feldspars minerals in parent material. Similar results reported by Ravikumar and Somashekar (2014) ${ }^{[7]}$.

\subsection{Phosphorus adsorption isotherm of different soils}

The $\mathrm{P}$ adsorption isotherms for the soils of Jabalpur is given in table 3.2. The value of equilibrium solution $P$ concentrations were found minimum in Alfisols (0.03 to $\left.8.95 \mu \mathrm{g} \mathrm{mL}^{-1}\right)$ and maximum in Inceptisols $(0.09$ to $10.95 \mu \mathrm{g}$ $\mathrm{mL}^{-1}$ ), but the adsorb $\mathrm{P}$ value was minimum in Inceptisols (19.01 to $290.41 \mu \mathrm{g} \mathrm{mL}^{-1}$ ) and maximum were recorded in Alfisols (19.64 to $\left.310.47 \mu \mathrm{g} \mathrm{mL}^{-1}\right)$. Similar Vertisols of JNKVV farm, where the value of equilibrium solution $\mathrm{P}$ concentrations were found in the range of $(0.13$ to $10.08 \mu \mathrm{g}$ $\left.\mathrm{mL}^{-1}\right)$, but the adsorb $\mathrm{P}$ values were (18.65 to $\left.299.13 \mu \mathrm{g} \mathrm{mL}^{-1}\right)$. The soil order Inceptisols have lowering of $\mathrm{P}$ adsorption isotherms as compared to both the soil orders (Alfisols and Vertisols). Which indicating a marked decrease in $\mathrm{P}$ adsorbed and an increase in equilibrium solution $\mathrm{P}$ concentration. Minimum $\mathrm{P}$ adsorption occurred in the Inceptisol soil order. The $\mathrm{P}$ adsorption isotherms for the soils of Jabalpur is given in table 4.2. The value of equilibrium solution $P$ concentrations were found in the range 0.03 to $8.95 \mathrm{mg} \mu \mathrm{g}$ $\mathrm{mL}^{-1}$ in Vertisols, 0.09 to $10.95 \mu \mathrm{g} \mathrm{mL}^{-1}$ in Inceptisols, and 0.13 to $10.08 \mu \mathrm{g} \mathrm{mL}^{-1}$ in Alfisols, but the adsorb $\mathrm{P}$ value were found in the range 19.64 to $310.47 \mu \mathrm{g} \mathrm{mL}^{-1}$ in Vertisols, 19.01 to $290.41 \mu \mathrm{g} \mathrm{mL}^{-1}$ in Inceptisols and 18.65 to $299.13 \mu \mathrm{g} \mathrm{mL}^{-1}$ in Alfisols. The graphical representation of equilibrium $\mathrm{P}$ concentration versus rate of $\mathrm{P}$ adsorbed on unit mass of soil colloid were used to calculate the maximum sorption capacity of the soils and the affinity of the soil to hold P. In all three soil orders, the equilibrium $\mathrm{P}$ solution and per unit $\mathrm{P}$ adsorption by soil colloids increased with increasing $\mathrm{P}$ addition (Dhillon et al., 2004) ${ }^{[3]}$. Similar results also reported by Rashmi et al., (2016) ${ }^{[16]}$.

\subsection{Phosphorus adsorption parameter}

The $\mathrm{P}$ adsorption data of the soils under different soil orders options fitted well to the classical Langmuir equation, with highly significant $\mathrm{R}^{2}$ values $0.993,0.995$ and 0.997 (Table 3.3) in the Alfisols, Inceptisols and Vertisols of JNKVV farm Jabalpur. The Langmuir $\mathrm{P}$ adsorption maxima (b) and bonding energy constant $(\mathrm{k})$ derived from the Langmuir isotherms of $\mathrm{P}$ adsorption by soil varied widely among different soil orders. The value of adsorption maxima (b) was found to be 412.99, 467.54 and $484.01 \mathrm{mg} \mathrm{P} \mathrm{kg}^{-1}$ in I3, I2 and I1 (Inceptisols) soil order with the mean value of $452.98 \mathrm{mg} \mathrm{P}$ $\mathrm{kg}^{-1}$ followed by $463.90,480.10$ and $497.36 \mathrm{mg} \mathrm{P} \mathrm{kg}^{-1}$ in $\mathrm{A} 3$, $\mathrm{A} 2$ and A3 (Alfisols) with the mean value of $480.89 \mathrm{mg} \mathrm{P} \mathrm{kg}$ 1 and maximum value of adsorption maxima (b) 526.01, 493.07 and $491.14 \mathrm{mg} \mathrm{P} \mathrm{kg}^{-1}$ in V3,V2 and V1 (Vertisol) soil order with the mean value of $504.26 \mathrm{mg} \mathrm{P} \mathrm{kg}^{-1}$. The bonding energy constant $(\mathrm{k})$ was found to be $0.131,0.143$ and $0.141 \mathrm{~L}$ $\mathrm{mg}^{-1}$ in Vertisols, Alfisols and Inceptisols soil order, respectively.

The Langmuir P adsorption maxima (b) and bonding energy constant $(\mathrm{K})$ derived from the Langmuir isotherms of $\mathrm{P}$ adsorption by soil varied widely among different soil orders. The highest $\mathrm{P}$ sorption maxima followed the order Vertisol (504.26 mg kg-1) >Alfisol (480.89 mg kg-1) >Inceptisol
(452.98 $\left.\mathrm{mg} \mathrm{kg}^{-1}\right)$. The phosphate adsorption isotherm gave a good fit in case of Langmuir $\left(r^{2}=0.993\right.$ to 0.997$)$ equations as presented in table 4.3. Similar results were obtained by Quang et al. (1996) ${ }^{[14]}$ and Thakur et al. (2004) ${ }^{[22]}$. High P sorption maxima in Vertisol was due to high clay content, whereas in Alfisol and Ultisol $\mathrm{Al}$ and $\mathrm{Fe}$ sorbed more P. The high $\mathrm{P}$ fixing capacity is a major constraint in these soils because > $80 \%$ of $\mathrm{P}$ is unavailable to crop uptake due to sorption, precipitation or both (White, 1981) ${ }^{[27]}$. The bonding energy constant (K) was found $0.131 \mathrm{~L} \mathrm{mg}^{-1}$ in Alfisols soil order and $0.140 \mathrm{~L} \mathrm{mg}^{-1}$ in Inceptisols soil order and the maximum bonding energy constant $(\mathrm{K})$ was found $0.143 \mathrm{~L} \mathrm{mg}^{-1}$ in Vertisols. The binding energy of the soils for $\mathrm{P}$ adsorption decreased with increase in surface coverage and interaction with molecules already adsorbed tends to increase with increasing surface coverage, which is in agreement with (Quang, 1996) ${ }^{[14]}$.

\subsection{Maximum $P$ buffering capacity (MPBC)}

The maximum $\mathrm{P}$ buffering capacity (MPBC) was found in range 60.07 to $70.89 \mathrm{~L} \mathrm{~kg}^{-1}$. In different soil orders the highest value of MPBC was found (Table 3.3) to be 67.68, 68.33 and $70.89 \mathrm{~L} \mathrm{~kg}^{-1}$ in A1, A2 and A3 (Alfisols) with the mean value $68.89 \mathrm{~L} \mathrm{~kg}^{-1}$ and the lowest of MPBC value was found to be 60.07, 63.57 and 68.01 $\mathrm{L} \mathrm{kg}^{-1}$ in I2, I1 and I3 (Inceptisols) with the mean value was $63.72 \mathrm{~L} \mathrm{~kg}^{-1}$. Whereas in Vertisols, the value of MPBC was found to be $64.31,66.44$ and $68.06 \mathrm{~L}$ $\mathrm{kg}^{-1}$ in site $\mathrm{V} 2, \mathrm{~V} 1$ and $\mathrm{V} 3$ with the mean value was $66.18 \mathrm{~L}$ $\mathrm{kg}^{-1}$, respectively. The phosphate buffering capacity (PBC or MBC) was found to be highest in Alfisols $\left(68.89 \mathrm{~L} \mathrm{~kg}^{-1}\right)$, Vertisols (66.18 $\mathrm{L} \mathrm{kg}^{-1}$ ) and Inceptisols (63.72 $\left.\mathrm{L} \mathrm{kg}^{-1}\right)$. The soils with high MBC namely Alfisols and Vertisols have high adsorption capacity and would maintain low $\mathrm{P}$ supply in soil solution for a longer period as compared to least buffered soils which can supply P to soil solution. On the other hand, soils with low buffering capacity will have more $\mathrm{P}$ in soil solution and will enhance P mobility in such soils.

\subsection{Standard Phosphorus Requirement (SPR)}

Amount of $\mathrm{P}$ adsorbed at $0.2 \mathrm{mg} \mathrm{L}^{-1}$ equilibrium solution $\mathrm{P}$ concentration is generally accepted as standard $\mathrm{P}$ requirement (SPR) of a soil for optimum crop yield. In the present study, the SPR of soil showed variation depending upon the different order of soils (Table 3.3). The value of SPR ranged from 3.31 to $9.61 \mathrm{mg} \mathrm{kg}^{-1}$. In different soil orders, the highest value of SPR was found to be $7.22,7.28$ and $9.61 \mathrm{mg} \mathrm{kg}^{-1}$ in I2, I1 and I3 (mean $8.04 \mathrm{mg} \mathrm{kg}^{-1}$ ) followed by Vertisols was $6.76,7.78$ and $7.80 \mathrm{mg} \mathrm{kg}^{-1}$ in V3, V1 and V2 (mean $7.45 \mathrm{mg} \mathrm{kg}^{-1}$ ) and the lowest SPR was found in Alfisols was 3.31, 3.38 and 4.68 $\mathrm{mg} \mathrm{kg}{ }^{-1}$ in A2, A1 and A3 (mean $3.79 \mathrm{mg} \mathrm{kg}^{-1}$ ), respectively. Amount of $\mathrm{P}$ adsorbed at $0.2 \mathrm{mg} \mathrm{L}^{-1}$ equilibrium solution $\mathrm{P}$ concentration is generally accepted as standard $\mathrm{P}$ requirement (SPR) of a soil for optimum crop yield. In the present study, the SPR of soil showed variation depending upon the different order of soils (Table 4.3). The amount of standard phosphorus requirement (SPR) for, Inceptisols, Vertisols and Alfisols was $8.04,7.45$ and $3.79 \mathrm{mg} \mathrm{kg}^{-1}$ respectively in $0.2 \mathrm{mg} \mathrm{P} \mathrm{L}^{-1}$ equilibrium soil solution concentration. The higher values of SRP in case of Inceptisols and Vertisols indicate the need for application of $\mathrm{P}$ fertilizers to maintain optimum crop production. From environmental point of view $\mathrm{P}$ leaching can occur at early stage from coarse textured Inceptisols compared to Vertisols and Alfisols Rashmi et al., (2016) ${ }^{[16]}$. 
3.7 Relationship of physico-chemical properties with phosphorus adsorption parameters in soil

Relationship of physico-chemical properties with phosphorus fractions in Vertisols soil order are presented in (Table 3.4) revealed that the $\mathrm{pH}$ had positive correlation with Adsorption maxima (b) $(r=0.993)$ and Maximum $\mathrm{P}$ buffering Capacity $(\mathrm{r}=0.715)$, but negative relationship with Bonding energy $(\mathrm{k})$ $(\mathrm{r}=-0.752)$ and Standard $\mathrm{P}$ requirement (SPR) $(\mathrm{r}=-0.982)$. The EC had negative relationship with $\mathrm{b}(\mathrm{r}=-0.769)$, but positive relationship with $\mathrm{k} \quad(\mathrm{r}=0.989)$. The OC had negative relationship with Maximum $\mathrm{P}$ buffering Capacity ( $\mathrm{r}=-0.928)$. The clay percent had negatively correlation with Maximum $\mathrm{P}$ buffering Capacity $(\mathrm{r}=-0.773)$. The CEC had significant negative correlation with Maximum $\mathrm{P}$ buffering Capacity $(\mathrm{r}=-$ $0.999 * *)$, but positive relationship with SPR $(\mathrm{r}=0.812)$, respectively.

In Alfisols soil order the correlation of physico-chemical properties with phosphorus fractions are presented in (Table 3.4) revealed that the $\mathrm{pH}$ had negative correlation with $\mathrm{b}(\mathrm{r}=-$ $0.975)$, but positively relationship with $\mathrm{k}(\mathrm{r}=0.916)$ and Maximum $\mathrm{P}$ buffering Capacity $(\mathrm{r}=0.839)$. The clay percent had negatively correlation with Maximum $\mathrm{P}$ buffering Capacity ( $\mathrm{r}=-0.865)$ and SPR $(\mathrm{r}=-0.959)$. The CEC had negative correlation with $\mathrm{b}(\mathrm{r}=-0.762)$, respectively.

Correlation of physico-chemical properties with phosphorus fractions in Inceptisols soil order are revealed that the EC had positive relationship with $\mathrm{b} \quad(\mathrm{r}=0.734)$, but negative relationship with $\mathrm{k} \quad(\mathrm{r}=-0.900)$, Maximum $\mathrm{P}$ buffering Capacity ( $r=-0.998)$ and SPR ( $r=-0.877)$. The OC had negative relationship with $\mathrm{b}(\mathrm{r}=-0.735)$. The clay percent had negatively correlation with $\mathrm{k} \quad(\mathrm{r}=-0.993)$, Maximum $\mathrm{P}$ buffering Capacity $(\mathrm{r}=-0.965)$ and $\mathrm{SPR}(\mathrm{r}=-0.986)$, but positive relationship with $b(\mathrm{r}=0.916)$. The $\mathrm{CaCO}_{3}$ had significant negative correlation with $\mathrm{b}(\mathrm{r}=-0.856)$, respectively.

Table 3.2: Phosphorus adsorption isotherm of different soils of JNKVV Farm, Jabalpur

\begin{tabular}{|c|c|c|c|c|c|c|}
\hline \multirow{3}{*}{$P \mu g \mathrm{~mL}^{-1}$} & \multicolumn{2}{|c|}{ Vertisols } & \multicolumn{2}{|c|}{ Alfisols } & \multicolumn{2}{|c|}{ Inceptisols } \\
\hline & Eq. C. $\left(\mu \mathrm{g} \mathrm{mL} L^{-1}\right)$ & Ads. $\left(\mu \mathrm{g} \mathrm{g}^{-1}\right)$ & Eq. C. $\left(\mu \mathrm{g} \mathrm{mL}^{-1}\right)$ & Ads. $\left(\mu \mathrm{g} \mathrm{g}^{-1}\right)$ & Eq. C. $\left(\mu \mathrm{g} \mathrm{mL} L^{-1}\right)$ & Ads. $\left(\mu \mathrm{g} \mathrm{g}^{-1}\right)$ \\
\hline & $\mathrm{C}$ & $\mathrm{x} / \mathrm{m}$ & $\mathrm{C}$ & $\mathrm{x} / \mathrm{m}$ & $\mathrm{C}$ & $\mathrm{x} / \mathrm{m}$ \\
\hline 2 & 0.135 & 18.651 & 0.036 & 19.644 & 0.099 & 19.013 \\
\hline 4 & 0.554 & 34.461 & 0.436 & 35.635 & 0.498 & 35.025 \\
\hline 8 & 1.869 & 61.308 & 2.113 & 58.873 & 2.180 & 58.204 \\
\hline 16 & 3.211 & 127.891 & 3.766 & 122.341 & 3.091 & 129.091 \\
\hline 24 & 3.302 & 206.983 & 4.074 & 199.263 & 4.568 & 194.325 \\
\hline 32 & 7.335 & 246.646 & 6.473 & 255.269 & 7.817 & 241.832 \\
\hline 40 & 10.087 & 299.132 & 8.953 & 310.473 & 10.953 & 290.471 \\
\hline
\end{tabular}

Table 3.3: Phosphorus adsorption parameters in surface soils of JNKVV Farms, Jabalpur

\begin{tabular}{|c|c|c|c|c|c|}
\hline Site & $\begin{array}{l}\text { Adsorption maxima } \\
\text { (b) }\left(\mathrm{mg} \mathrm{P} \mathrm{kg}^{-1}\right)\end{array}$ & $\begin{array}{l}\text { Bonding energy } \\
(\mathrm{K})\left(\mathrm{L} \mathrm{mg}^{-1}\right)\end{array}$ & \begin{tabular}{|c|} 
Maximum $P$ buffering \\
Capacity $\left(\mathrm{L} \mathrm{kg}^{-1}\right)$
\end{tabular} & \begin{tabular}{|c|} 
Amount of p sorbed(mg kg-1) at \\
$0.2 \mathrm{mg} \mathrm{P} \mathrm{L}^{-1}$ of solution (SPR) \\
\end{tabular} & $\mathbf{R}^{2}$ \\
\hline (V1) & 491.14 & 0.135 & 66.44 & 7.78 & 0.997 \\
\hline (V2) & 493.07 & 0.130 & 64.31 & 7.80 & 0.997 \\
\hline (V3) & 526.01 & 0.129 & 68.06 & 6.76 & 0.997 \\
\hline Mean & 504.26 & 0.131 & 66.18 & 7.45 & 0.997 \\
\hline (A1) & 497.36 & 0.136 & 67.68 & 3.38 & 0.993 \\
\hline (A2) & 480.10 & 0.142 & 68.33 & 3.31 & 0.992 \\
\hline (A3) & 463.90 & 0.153 & 70.89 & 4.68 & 0.993 \\
\hline Mean & 480.89 & 0.143 & 68.89 & 3.79 & 0.993 \\
\hline (I1) & 484.01 & 0.131 & 63.57 & 7.28 & 0.996 \\
\hline (I2) & 467.54 & 0.128 & 60.07 & 7.22 & 0.996 \\
\hline (I3) & 412.99 & 0.165 & 68.01 & 9.61 & 0.993 \\
\hline Mean & 452.98 & 0.141 & 63.72 & 8.04 & 0.995 \\
\hline
\end{tabular}

Table 4.4: Relationship of physico-chemical properties with phosphorus adsorption parameters in soil

\begin{tabular}{|c|c|c|c|c|c|}
\hline Soil orders & & Adsorption maxima (b) & Bonding energy (K) & $\begin{array}{l}\text { Maximum P buffering } \\
\text { Capacity }\end{array}$ & $\begin{array}{c}\text { Standard P requirement } \\
\text { (SPR) }\end{array}$ \\
\hline \multirow{6}{*}{ Vertisols } & $\mathrm{pH}$ & 0.993 & -0.752 & 0.715 & -0.982 \\
\hline & $\mathrm{EC}$ & -0.769 & 0.989 & -0.225 & 0.726 \\
\hline & $\mathrm{OC}$ & -0.510 & -0.292 & -0.928 & 0.569 \\
\hline & Clay & -0.230 & -0.573 & -0.773 & 0.293 \\
\hline & CEC & -0.772 & 0.04 & $-0.999 *$ & 0.812 \\
\hline & $\mathrm{CaCO}_{3}$ & -0.066 & -0.700 & -0.657 & 0.131 \\
\hline \multirow{6}{*}{ Alfisols } & $\mathrm{pH}$ & -0.975 & 0.916 & 0.839 & 0.687 \\
\hline & EC & 0.258 & -0.074 & 0.088 & 0.321 \\
\hline & $\mathrm{OC}$ & 0.158 & 0.028 & 0.189 & 0.416 \\
\hline & Clay & 0.641 & -0.772 & -0.865 & -0.959 \\
\hline & CEC & -0.762 & 0.629 & 0.495 & 0.276 \\
\hline & $\mathrm{CaCO}_{3}$ & 0.611 & -0.453 & -0.303 & -0.070 \\
\hline \multirow{6}{*}{ Inceptisols } & $\mathrm{pH}$ & 0.548 & -0.279 & 0.099 & -0.328 \\
\hline & EC & 0.734 & -0.900 & $-0.998 *$ & -0.877 \\
\hline & $\mathrm{OC}$ & -0.735 & 0.504 & 0.146 & 0.548 \\
\hline & Clay & 0.916 & -0.993 & -0.965 & -0.986 \\
\hline & CEC & 0000 & -0.291 & -0.627 & -0.242 \\
\hline & $\mathrm{CaCO}_{3}$ & -0.856 & 0.668 & 0.342 & 0.705 \\
\hline
\end{tabular}




\section{References}

1. Bouyoucous GT. Improved hydrometer method for making particle size analysis of soils. Argonomy Journal. College of Tropical Agriculture and Human Resources, University of Hawaii. 1962; 54:464-465.

2. Dhakad R. Assessment of Fertility Status of Jawaharlal Nehru Krishi Vishwa Vidyalaya Farms for Developing Nutrient Management Strategies. M.Sc. Thesis JNKVV, Jabalpur (M.P.), 2017.

3. Dhillon NS, Dhesi TS, Brar BS. Phosphate sorption desorption characteristics of some Ustifluvents of Punjab. Journal of Indian Society of Soil Science. 2004; 52:1722.

4. Dubliya J. Soil health assessment of dusty acre farm under JNKVV, Jabalpur, Madhya Pradesh. M.Sc. Thesis, JNKVV, Jabalpur (M.P.), 2011.

5. Fox RL, Kamprath EJ. Phosphate Sorption Isotherms for Evaluating the Phosphate Requirements of Soils. Soil Science Society of America Journal. 1970; 34:902-907.

6. Hue NV, Ikawa H, Huang X. Predicting soil phosphorus requirements. In Plant nutrient management in Hawaii soils, ed. J A. Silva and R. Uchida. Honolulu. 2000, 9599.

7. Jackson ML. Soil Chemical Analysis. Prentice Hall of India, Private Limited New Delhi, 1973, 498.

8. Kulkarni R, Gupta GP, Bangar KS. A note on predicting management of kheri and adhartal series of soils. Journal of Indian Society Soil of Science. 1986; 34:641-643.

9. Kuo S, Jellum EJ, Pan WL. Influence of phosphate sorption parameters on the desorption of phosphate by various extractants. Soil Science Society of America Journal. 1988; 52:974-979.

10. Majumdar B, Kumar K, Venkatesh MS, Ram P. Effect of liming on phosphate adsorption and desorption behaviour of acidic Alfisols and Entisol of Meghalaya. Journal of Indian Society of Soil Science. 2005; 53:188-193.

11. Matike DME, Ekosse GIE, Ngole VM. Physico-chemical properties of clayey soils used traditionally for cosmetics in Eastern Cape, South Africa. International Journal of the Physical Sciences. 2011; 6(33):7557-7566.

12. Olsen SR, Cole CV, Vatanabe FS, Dean LA. Estimation of available phosphorus in soil by extraction with sodium bicarbonate. Circular United States, Department of Agriculture. 1954; 93(9):1-19.

13. Pathak NKS. A study of the nutrient status of Adhartal series of Vertisols. M.Sc. Thesis, JNKVV, Jabalpur (M.P.), 1983.

14. Quang SR, Thai VC, Linn TTT, Dutey JE. Phosphorus sorption in soils of the Mekong Delta (Vietnam) as described by the binary Langmuir equation. European Journal of Soil Science. 1996; 47:113-123.

15. Raghuwanshi DP, Tembhare BR, Gupta GP. Taxonomy of black and associated soils of Jabalpur, Pawarkheda and Indore Research Farms of M.P. JNKVV Research Journal. 1992; 26:12-14.

16. Rashmi I, Parama VRR, Biswas AK. Phosphate sorption parameters in relation to soil properties in some major agricultural soils of india. SAARC J Agri. 2016; 14(1):01-09.

17. Ravikumar P, Somashekar RK. Spatial distribution of macronutrients in soils of Markandeya river basin, Belgaum, Karnataka, India. Proceedings of the International Academy of Ecology and Environmental Science. 2014; 4(2):81-94.
18. Saha S, Datta A, Sanyal SK. Phosphate sorptiondesorption characteristics of some acid soils. Journal of Indian Society of Soil Science. 1999; 47:34-39.

19. Singh R, Puri G, Dilliwar P, Amule FC. Soil health assessment of Adhartal series under Jawaharlal Nehru Krishi Vishwa Vidyalaya. National conference on soil health: A key to unlock and sustain production potential September 3-4. Held at Department of Soil Science and Agricultural Chemistry, College of Agriculture, JNKVV, Jabalpur (M.P.), 2014.

20. Subbiah BV, Asija GL. A rapid procedure for the determination of available nitrogen in soils. Current Science. 1956; 25(8):259-260.

21. Tekchand, Tomar NK. Correlation of soil properties with $P$ fixation in some alkaline calcareous soil of north-west Asia. Arid Soil Research and Rehabilitation. 1993; 37:7791.

22. Thakur SK, Tomar NK, Pandeya SB. Sorption of phosphate on pure and cadmium-enriched calcium carbonate and clay. Journal of Indian Society of Soil Science. 2004; 52:23-28.

23. Tomar VS. Studies on magnesium in Madhya Pradesh. M.Sc. Thesis, JNKVV, Jabalpur (M.P.), 1968.

24. Tripathi PN. Detailed soil survey of different sections of JNKVV Farm at Jabalpur, Madhya Pradesh. M.Sc. Thesis, JNKVV, Jabalpur (M.P.), 1998.

25. Tripathi SK. Evaluation of soil fertility status and quality of irrigation water of JNKVV Farms at Jabalpur, Madhya Pradesh. M.Sc. Thesis, JNKVV, Jabalpur (M.P.), 1994.

26. Walkley A, Black CA. An examination of Degt-Jreff method for determination soil organic matter and proposal for modification of the chromic acid titration method. Soil Science. 1934; 37:29-38.

27. White RE. Retention and release of phosphate by soil and soil constituents. In: Tinker PB, editor. Soils and agriculture, critical reports on applied chemistry. Oxford: Blackwell, 1981; 2:71-114.

28. Yang X, Post WM. Phosphorus transformations as a function of pedogenesis: A synthesis of soil phosphorus data using Hedley fractionation method. Bio geosciences. 2011; 8(10):2907-2916. 